\title{
Precipitation impacts on earthen architecture for better implementation of cultural resource management in the US Southwest
}

\author{
Sharlot Hart ${ }^{\text {* }}$, Kara Raymond ${ }^{1}$, C. Jason Williams², Justin Johnson ${ }^{3}$, Jacob DeGayner ${ }^{1}$ and \\ Matthew C. Guebard ${ }^{1 *}$ (D)
}

\begin{abstract}
Changing seasonal precipitation patterns prompted by climate change are likely causing increasing degradation of adobe architecture in the American Southwest. This deterioration includes surface erosion and catastrophic collapse. This study examines the impact of changing rainfall patterns on untreated adobe walls to understand how damage occurs and anticipate future impacts. To complete the study, we constructed 20 adobe test walls. Using a portable rain simulator, each wall was subjected to two rainfall experiments: high-intensity rainfall simulations (rain intensity variable) and low-intensity rainfall simulations (rain event number variable). Wall-degradation metrics (material loss, volume loss, affected surface area, and cavity depth) were calculated for each wall using pre- and post-simulation LiDAR scans. Internal wall moisture was also measured with embedded volumetric water content sensors. In the high-intensity experiment, the lines of best-fit for material loss and affected surface area show that surface erosion increases with rain intensity, while cavity depth remains consistent. Linear models and post-hoc tests indicate material loss and affected surface area is significantly different for each high-intensity rainfall treatment. Furthermore, the interior of each wall remained relatively dry demonstrating that rain intensity is not a strong predictor of interior wall moisture. In the low-intensity rainfall experiment, the rainfall simulations yielded statistically similar erosion and interior wall moisture results. Greater infiltration occurred under low-intensity long-duration rain conditions, while greater surficial damage occurred under high-intensity rain conditions. In conclusion, changing weather regimes are bringing more intense rainfall events to the arid American Southwest. This study suggests that more frequent high intensity rain events will cause increasing damage to adobe walls. Resource managers will need to adapt current management strategies to account for this change.
\end{abstract}

Keywords: Earthen architecture, Adobe, Climate change, Rain intensity, Erosion, Historic, Tumacácori National Historical Site, National Park Service

\footnotetext{
*Correspondence: sharlot_hart@nps.gov; matt_guebard@nps.gov

${ }^{1}$ National Park Service, Southern Arizona Office, 3636 North Central

Avenue, Suite 410, Phoenix, AZ 85012, USA

Full list of author information is available at the end of the article
}

\begin{abstract}
Introduction
Over the last decade, cultural resource managers working for the United States National Park Service (NPS) have noted increasing damage to earthen architecture from rainfall. Rainwater from storm events has caused erosion, material loss, and even catastrophic collapse of adobe architecture [1]. For instance, Tumacácori National Historical Park (NHP), near Tucson, Arizona, has suffered
\end{abstract}


four wall collapses since 2010. This damage appears to happen when rain penetrates the existing protective lime shelter and saturates underlying adobe, causing structural failure. The collapses at Tumacácori occurred during long-duration storm events in both winter and summer. The summer storm events also included short periods of high-intensity rainfall.

To adapt, resource managers must understand the relationship of rainfall intensity and resource damage and develop appropriate strategies for protecting fragile architectural fabric under changing precipitation regimes. However, most studies of the architectural resilience of adobe have tested preservation treatments instead of hydrologic mechanisms. The research described here provides baseline data on material loss to help advance our understanding of how to protect historic adobe structures under predicted future climate conditions. Over the course of eight months, an interdisciplinary team of archaeologists, masons, and historic preservationists, with the help of hydrologists, soil scientists, geographers, climate data, and computers, exposed untreated test walls to high- and low-intensity rainfall simulations and used LiDAR scanning to record the effects.

\section{Adobe structures and climate change}

Much of the available climate change data regarding risks to archaeological sites and historic properties focuses on the impact of sea level rise. The dry conditions typical of the US Southwest are generally considered favorable for the long-term preservation of artifacts and architecture. However, changing regional precipitation patterns relative to rainfall intensity are likely to cause increasing damage to earthen architecture. Projecting future precipitation patterns for this area is challenging due to high inter-year variability and the complex interplay of seasonal rain-bearing systems [2-6]. Shifts in the North American Monsoon weather system and Pacific tropical cyclones will affect the summer and early autumn rainfall amount, frequency, and intensity. Similarly, shifts in Pacific cold fronts and atmospheric rivers will affect winter rainfall patterns. These four weather systems will have a range of impacts on precipitation across the American Southwest.

Many climate change models project an increasing frequency of extreme rain events in the region during the North American Monsoon [7-11]; even while annual precipitation is projected to decrease, though the seasonality of the decrease varies $[7,9,12-18]$. However, a few studies have also found no trend in extreme events $[13,15]$. An analysis of extreme precipitation during the twentieth and early twenty-first centuries across the Southwest has already found an increasing trend in the 1-day, 20-year return precipitation value [14]. In southeastern Arizona, daily and subdaily precipitation intensities increased between 1961 and 2017 [3].

Tropical cyclones may also drive increases in extreme storms across the US Southwest. Remnant moisture from decaying Pacific tropical storms can produce large rain totals over multiple days in Arizona and other southwestern states [19]. These long-duration storm events create conditions that can drastically increase erosion and internal moisture of adobe walls, leading to catastrophic damage. Compared to present day weather patterns, projections indicate a substantial increase in category 4-5 tropical cyclones in the northeast Pacific Ocean by the late twenty-first century [20,21]. Similar increases may be seen in the number of remnant storms moving inland. These projected changes in rainfall patterns highlight the need to understand how different types of rain events affect earthen architecture and the efficacy of existing preservation methods. Indeed, one of the storms resulting in wall collapse at Tumacácori NHP was a remnant hurricane.

Regardless of storm type, moisture is a significant factor affecting the deterioration of earthen structures $[1$, 22]. Numerous hydrologic processes influence the rate and severity of decay [23]. Wetting and drying cycles may induce swelling of clay particles, resulting in cracking and reduced structural stability that increase opportunities for water ingress [1]. Freeze-and-thaw cycles similarly result in cracking via thermal expansion of freezing water [24]. Earthen foundations are particularly vulnerable to moisture-related deterioration due to capillary rise of water absorbed from the adjacent ground, and direct wetting from rain splash. When saturated, building materials may take on more fluid-like properties, making them prone to mass wasting or collapse. Energy from rainfall and resulting over-structure flow can detach particles and result in damage and deterioration [25].

\section{Precipitation at Tumacácori NHP}

Changes in precipitation amount and timing are becoming apparent at the Tumacácori NHP Cooperative Observer Program rain gage (USC000028865). Mean annual total rainfall at the park from 2001-2020 was $39.5 \mathrm{~cm}$, approximately $3.0 \mathrm{~cm}$ down from the $1971-2000$ annual mean. Annual precipitation for these two periods are not statistically different due to high inter-year variability. Rainfall in winter and spring decreased $29 \%$ and $23 \%$ respectively between the two measurement periods. Additionally, the summer monsoon rainfall has slightly increased by $3 \%(0.8 \mathrm{~cm})$ and now accounts for $61 \%$ of the annual rainfall total. The daily precipitation data from USC000028865 are too coarse to directly analyze changes in storm intensity and frequency. 


\section{Historical and contemporary erosion studies on earthen architecture}

To protect historic adobe structures from the effects of weathering, a variety of preservation treatments may be applied. The construction and monitoring of test walls is a standard practice used to develop and assess the performance of those treatments prior to application. This includes testing the use of protective shelter coatings on adobe walls and monitoring the mechanisms of weathercaused deterioration [1,22]. Test walls allow managers to evaluate the durability and effectiveness of a proposed treatment and anticipate potential damage from future weather before the treatment is implemented on irreplaceable historic fabric. At NPS sites in the US Southwest, test-wall projects have assessed the effectiveness of preservation treatments at places like Pecos National Historical Park, where L-shaped test walls were used to evaluate performance of the additive, Rhoplex E330, in protective veneers [26]. Similar projects have tested amended plasters at Casa Grande Ruins National Monument, Fort Bowie National Historic Site, and Tumacácori NHP.

Previous adobe test-wall studies have tended to focus on the performance of soil amendments. The Fort Selden Adobe Test Wall Project, overseen by The Getty Conservation Institute, is a standard bearer in that world. The purpose of their Phase I project was "to test a wide range of protective coatings, wall caps, and wall foundation treatments" [27]. Oliver's 2000 report provided important performance data on soil amendments and was based on 15 years' worth of exposure. The Fort Selden project focused on gathering longitudinal data for the protection of already deteriorating sites. When that project started in 1985 there was little concern for the changing weather patterns facing resource managers today.

\section{Historical hydrologic/erosion work on adobe structures and rainfall simulation technologies as a new tool}

Rainfall significantly impacts the durability of earthen structures and several studies have attempted to measure the hydraulic properties of earthen building materials [23]. Much of this previous work deployed immersion and/or absorption tests [28-30]. Immersion tests assess the rate at which a building material becomes saturated by submerging that material and then weighing it periodically. Although useful in its simplicity, submerged conditions (e.g., from flooding) are rare, and immersion tests likely overestimate the rate at which a medium conducts water during natural rainfall. Absorption tests identify the sorptive properties of earthen materials (i.e., capillarity) during infiltration. In absorption tests, a building material is placed atop a saturated surface (e.g., sponge, wet sand) and is then weighed regularly to determine its ability to absorb moisture. Researchers have also measured the erodibility of earthen building materials through various abrasion and drip tests [31-33].

The application of rainfall simulations to earthen structures offers an opportunity to apply advances in other fields of study to the preservation of historic structures. Rainfall simulations have been used extensively in hydrologic studies to quantify infiltration, runoff, and surface soil erosion [23, 34, 35]. However, these studies have been less frequently applied to assessing the durability of earthen building materials-though some examples do exist [36]. Ogunye and Boussabaine [37] designed and utilized a "rainfall test rig" to expose soil blocks to high-intensity $\left(150 \mathrm{~mm} \mathrm{~h}^{-1}\right)$ rainfall. Hall [38] created a "climatic simulator" with controls on temperature and relative humidity that could apply various storm sequences to entire wall surfaces. Spray tests, which are less precise, have also been used to study erodibility [39].

This study details our efforts to systematically investigate the impact of high and low-intensity rain events on adobe structures using test walls and systematic rain simulations. The intent of the project was to better understand the mechanisms associated with varying rainfall intensities and storm types that result in damage to adobe walls. The study was conducted at the NPS Desert Research Learning Center (DRLC) in Tucson, Arizona. Two of the authors along with others built a total of 20 adobe test walls on site and exposed them to a series of rainfall simulations representing current and predicted storm events. Sensors embedded in each wall monitored for moisture before, during, and after each simulation. LiDAR scans were conducted to quantify material and volume losses and other degradation metrics for unamended adobe.

\section{Material and methods \\ Adobe wall construction Sourcing soil and building the walls}

Test walls were constructed using materials and methods consistent with the historic fabric comprising adobe buildings at Tumacácori NHP. Materials included soil and sand that matched the clay content and color attributes of original eighteenth century construction. National Park Service staff use these same materials for preservation maintenance, and they have proven successful for repairs and small-scale reconstructions. Using these materials will enable extrapolation of the research findings to actual structures of the same composition.

Wall construction was undertaken as two trainings for NPS cultural resource personnel and their cooperators at the NPS DRLC. These trainings were led by three instructors experienced in both masonry and adobe in 
Table 1 Physical properties of block and mortar samples

\begin{tabular}{|c|c|c|c|}
\hline Property & Block & Mortar & Analytical Method \\
\hline Bulk density $\left(\mathrm{g} \mathrm{cm}^{-3}\right)$ & 1.87 & 1.72 & ASTM D2937-17e2 [41] \\
\hline Particle density $\left(\mathrm{g} \mathrm{cm}^{-3}\right)$ & 2.68 & 2.68 & \\
\hline Estimated total porosity $\left(\mathrm{cm}^{3} \mathrm{~cm}^{-3}\right)$ & 0.301 & 0.358 & \\
\hline Saturated hydraulic conductivity $\left(\mathrm{cm} \mathrm{h}^{-1}\right)$ & 0.35 & 0.47 & ASTM D2434-68 [42] \\
\hline Liquid limit (\% water content) & 21 & 22 & ASTM D4318-17e1 [43] \\
\hline Plastic limit (\% water content) & 16 & 14 & \\
\hline
\end{tabular}

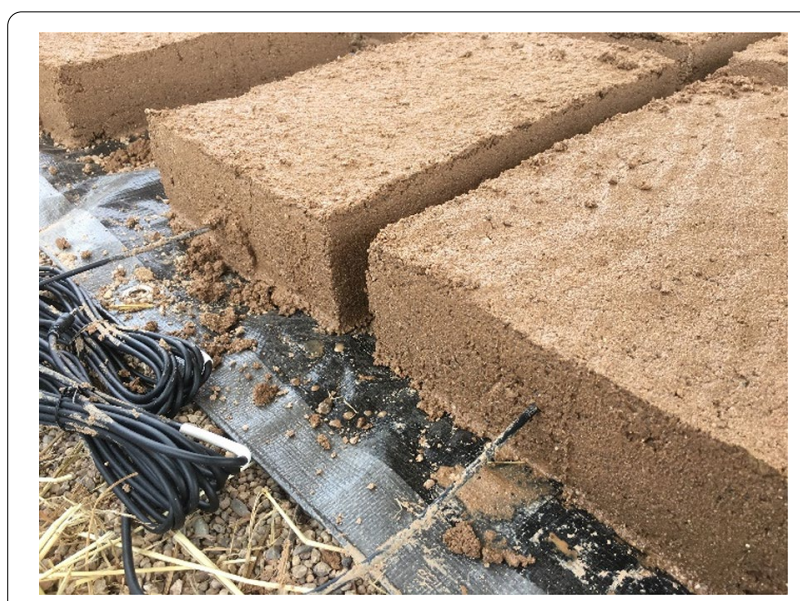

Fig. 1 Adobe blocks drying, showing placement of sensors

southern Arizona: the head mason and a retired mason from Tumacácori NHP, and a US Forest Service historic preservation specialist. During the first training in early August 2018, participants created adobe blocks. The dimensions of each block $(41 \mathrm{~cm} \times 25 \mathrm{~cm} \times 9 \mathrm{~cm})$ match the size of original blocks found at the Mission Los Santos Angeles de Guevavi (part of Tumacácori NHP). Moisture sensors were placed horizontally in the blocks as they were being made to ensure the adobe was in full contact with the sensors (Fig. 1). Each sensor was placed $5 \mathrm{~cm}$ from a block's top and bottom faces, with the tip of each sensor $12 \mathrm{~cm}$ from the outside edge.

During the second training, in early October 2018, twenty adobe test walls were built. The test walls were sized and spaced ( $>2 \mathrm{~m}$ apart) to accommodate placement of the rainfall simulator. Each adobe wall was 9 courses $(1.0 \mathrm{~m})$ tall, 1 block $(0.41 \mathrm{~m})$ wide, and three wythes $(0.81 \mathrm{~m})$ thick. Every other course had two whole blocks centered and a split block on either end. A block with a volumetric water-content sensor was placed in the eighth course of each wall ( $0.80 \mathrm{~m}$ above ground surface). Walls were left bare, with no cap or shelter coat. Physical properties and characteristics of adobe block and mortar samples are summarized in Table 1 and Fig. 2 [40].

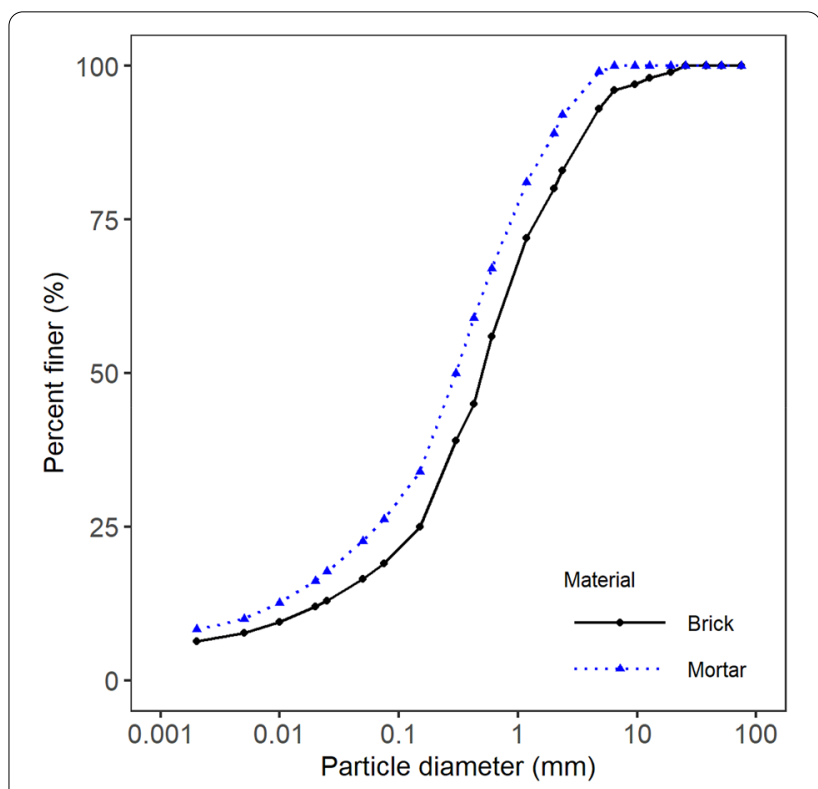

Fig. 2 Block and mortar particle size distributions, methods ASTM D 6913-17 and ASTM C136-14 [44, 45]

\section{Rain simulator \\ High-intensity rainfall}

The first experiment evaluated the effects of high-intensity storms. Assessments of wall wetting and degradation were determined by material loss, volume loss, affected surface area, cavity depth, and relative moisture content. Treatments for the high-intensity experiments lasted $30 \mathrm{~min}$ and simulated the following storm types: (1) Control: no rainfall, (2) One-year Storm: $3.6 \mathrm{~cm} \mathrm{~h}^{-1}$, (3) 25-year Storm: $8.5 \mathrm{~cm} \mathrm{~h}^{-1}$, and (4) 100-year Storm: $10.6 \mathrm{~cm} \mathrm{~h}^{-1}$. The selected rainfall intensities were based on the return interval for one-year, 25-year, and 100-year storms as estimated for the Tumacácori NHP weather station, which is $79 \mathrm{~km}$ from the DRLC [46]. The 25-year and 100-year treatments are proxies for higher intensity storms that are projected to become more frequent. The 30-min "storms" resulted in total rainfall amounts of $1.8 \mathrm{~cm}, 4.2 \mathrm{~cm}$, and $5.3 \mathrm{~cm}$, respectively. A single treatment was applied to each wall in early to mid-November 
2018. Each treatment was randomly assigned to five different walls ( 1 treatment per wall, $n=5$ walls per each of the four treatments).

\section{Low-intensity rainfall}

The second experiment, for low-intensity rainfall, was conducted from late May to early June 2019, on the same test walls used for the high-intensity simulations. This experiment was intended to assess the effects of prolonged low-intensity rainfall on wall wetting and degradation. Treatments were conducted as follows: (1) Control: no rainfall, (2) 1-event: $3.9 \mathrm{~cm}$ rainfall, 4-h duration (240 $\mathrm{min})$, and (3) 2-event: $3.9 \mathrm{~cm}$ rainfall, 4 -h duration ( $80 \mathrm{~min} / 160 \mathrm{~min})$. The control treatment $(n=5)$ utilized the same original five control test walls from the high-intensity rainfall experiments. Each of the remaining 15 test walls were randomly assigned either the 1 -event $(n=8)$ or 2 -event $(n=7)$ treatment. The simulated rainfall was applied to each wall at an intensity of $1.6 \mathrm{~cm} \mathrm{~h}^{-1}$ in ten successive 15 -min sequences, each followed by a 9 -min period without rainfall.

The 1-event and 2-event experiments yielded a total rainfall of $3.9 \mathrm{~cm}$ over the full simulation period (240 $\mathrm{min})$, at an average intensity of $0.97 \mathrm{~cm} \mathrm{~h}^{-1}$. The 1 -event treatment received the low-intensity rainfall application over a continuous 240 -min period and was equivalent to a rain event at Tumacácori NHP with a 2-5 year recurrence interval [46]. The 2-event treatment received the same low-intensity rainfall application over an 80 -min period and a 160 -min period, separated by a 48-h hiatus, and was equivalent to a multi-day rain event that occurred more frequently than once a year [46]. Test walls were exposed to ambient conditions during the hiatus. The sampling design ensured that $2-3$ walls from each treatment type of high-intensity rainfall in 2018 were included in both the 1-event and 2-event treatments in 2019.

\section{Equipment}

All rainfall simulations were conducted by the US Department of Agriculture, Agricultural Research Service (ARS) staff, using a portable single-nozzle, Meyer and Harmon-type oscillating-arm rainfall simulator [47] raised $3 \mathrm{~m}$ above the ground surface (Fig. 3). The simulator design and operation were described in previous erosion studies by Pierson and others [48, 49]. To account for rainfall intensity and kinetic-energy relationships [47, 50], high-intensity simulations were conducted using a VeeJet $80-100$ nozzle, while low-intensity simulations used a VeeJet $80-70$ nozzle. Simulator nozzles were pressurized to $41 \mathrm{~N} \mathrm{~m}^{2}$

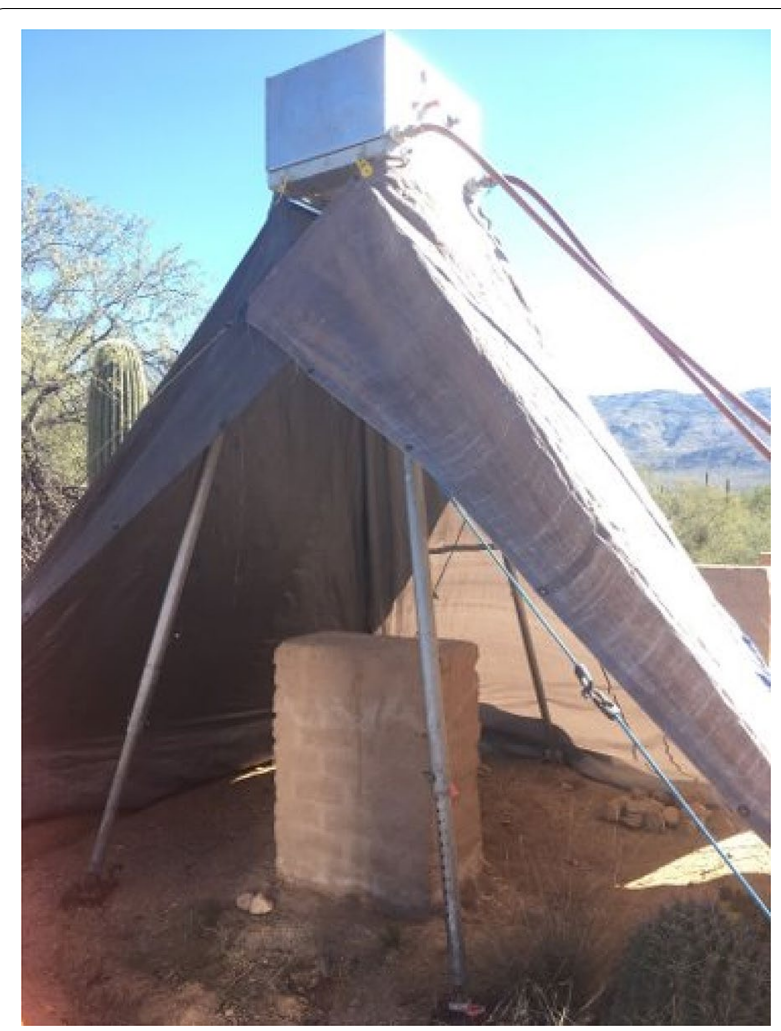

Fig. 3 Adobe test wall with rainfall simulator and windscreen set up

Table 2 Nozzle equipment outputs

\begin{tabular}{|c|c|c|c|}
\hline Experiment & Nozzle type & $\begin{array}{l}\text { Kinetic energy at } \\
\text { ground surface } \\
\left(\mathrm{kJ} \mathrm{ha} \mathrm{hm}^{-1} \mathrm{~mm}^{-1}\right)\end{array}$ & $\begin{array}{l}\text { Mean } \\
\text { droplet size } \\
(\mathrm{mm})\end{array}$ \\
\hline High-intensity & $80-100$ & 200 & 2 \\
\hline Low-intensity & $80-70$ & 120 & 1 \\
\hline
\end{tabular}

to match settings described and tested by Meyer and Harmon [47]. The VeeJet $80-100$ and $80-70$ nozzles produced rainfall with kinetic energy at the ground surface of approximately $200 \mathrm{~kJ} \mathrm{ha}^{-1} \mathrm{~mm}^{-1}$ and $120 \mathrm{~kJ} \mathrm{ha}^{-1} \mathrm{~mm}^{-1}$, respectively. Mean droplet sizes were $2 \mathrm{~mm}$ and $1 \mathrm{~mm}$ for the $80-100$ and $80-70 \mathrm{noz}-$ zles, respectively (Table 2) [47]. Information on nozzle types and equipment outputs are shown in Table 2.

The simulator was calibrated daily for each target intensity by simulating rainfall over a calibration pan for five minutes [49]. All simulations were controlled for wind by tarping around the simulator and associated test wall. After LiDAR scanning (described below) and a brief drying period, test walls were covered with protective tarps following the high-intensity rainfall experiments in 2018. All walls remained tarped until 
initiation of the low-intensity rainfall experiments in 2019.

\section{LiDAR application}

A Surphaser ${ }^{\circledR}$ Model 10 (Basis Software, Redmond, Washington, USA) laser scanner was used to measure test walls in 3D space before and after both the high- and low-intensity rainfall simulations. The Model 10 is a tripod-mounted hemispherical Class 1 laser scanner that records precise point coordinates by emitting a constant laser pulse and computing distances based on the measured phase shift of the signal. The margin of error for these measurements is likely to remain under one millimeter for distances within $15 \mathrm{~m}$ of the scanner [51].

To improve accuracy, distances between the scanner and walls were intentionally limited to reduce the effects of beam diameter and other range-based errors. Two levels of registration were used to compute geometric differences and allow for spatial comparison of datasets. First, a mixture of $150 \mathrm{~mm}$ and $200 \mathrm{~mm}$ spherical reference targets were distributed across the study area. High densities of measured points across the surface of each sphere allowed registration software to calculate the geometric centroid of each target, resulting in common points from which to base a 3D least-squares registration solution. Second, permanent control points were used to register each scanning epoch (measurement event) to the same coordinate space. Five $150 \mathrm{~mm}$ target spheres were mounted on short sections of permanently installed metal pipe. The spherical geometry of the targets and the permanent metal pipe ensured targets could be identified and located in subsequent scans (Fig. 4).

Test walls were recorded in four scanning epochs, each consisting of approximately 30 scans. The epochs

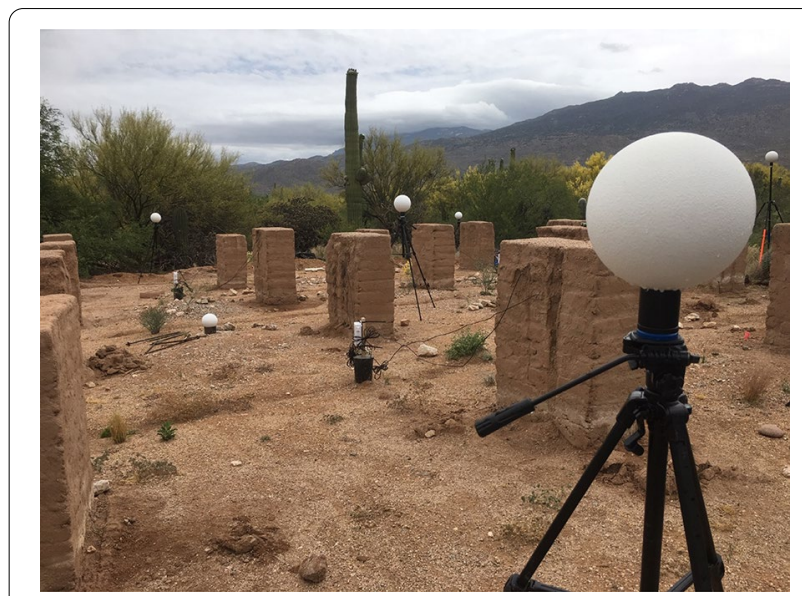

Fig. 4 LiDAR scanning equipment and test walls during Epoch II. Photo NPS/Alice W. Biel are defined here as Epochs I and II (before and after the high-intensity rainfall experiment in 2018) and Epochs III and IV (before and after the low-intensity rainfall experiment in 2019). Measured and adjusted locations of control points from each scanning epoch were compared to the global mean location derived from all four epochs. As shown in Table 3, this resulted in a root mean square error (RMSE) of $0.58 \mathrm{~mm}$.

Each scanning epoch was processed and registered in FARO Scene software (SCENE, version 2019.2), and then co-registered with the other epochs using the five permanent control points. Standard data filtration processes were applied to remove stray points and weak signal returns. Wall-degradation metrics (material loss, volume loss, affected surface area, and cavity depth) were calculated for each wall using the before and after LiDAR scans.

The rainfall experiments caused debris from mass wasting to mound up at the base of each wall. We defined reference planes above this level and removed all surfaces below the plane for both the before and after models. Material (\%) and volume losses $\left(\mathrm{cm}^{3}\right)$ were derived as the relative difference between pre- and post-treatment wall volumes. Scanning epochs were aggregated into singlepoint clouds and converted to polygonal meshes at a

Table 3 Mean control-point residuals from laser scanning

\begin{tabular}{ll}
\hline Observation (epoch and CP ID) & $\begin{array}{l}\text { 3D Distance from } \\
\text { geometric mean } \\
\text { (mm) }\end{array}$ \\
\hline ICP1 & 0.338 \\
ICP2 & 1.526 \\
ICP3 & 0.145 \\
ICP4 & 0.223 \\
ICP5 & 0.124 \\
II CP1 & 0.429 \\
II CP2 & 0.674 \\
II CP3 & 0.243 \\
II CP4 & 0.317 \\
II CP5 & 0.224 \\
II CP1 & 0.861 \\
II CP2 & 1.129 \\
II CP3 & 0.320 \\
II CP4 & 0.509 \\
II CP5 & 0.164 \\
IV CP1 & 0.653 \\
IV CP2 & 0.577 \\
IV CP3 & 0.262 \\
IV CP4 & 0.338 \\
IV CP5 & 0.232 \\
RMSE & 0.58 \\
\hline
\end{tabular}




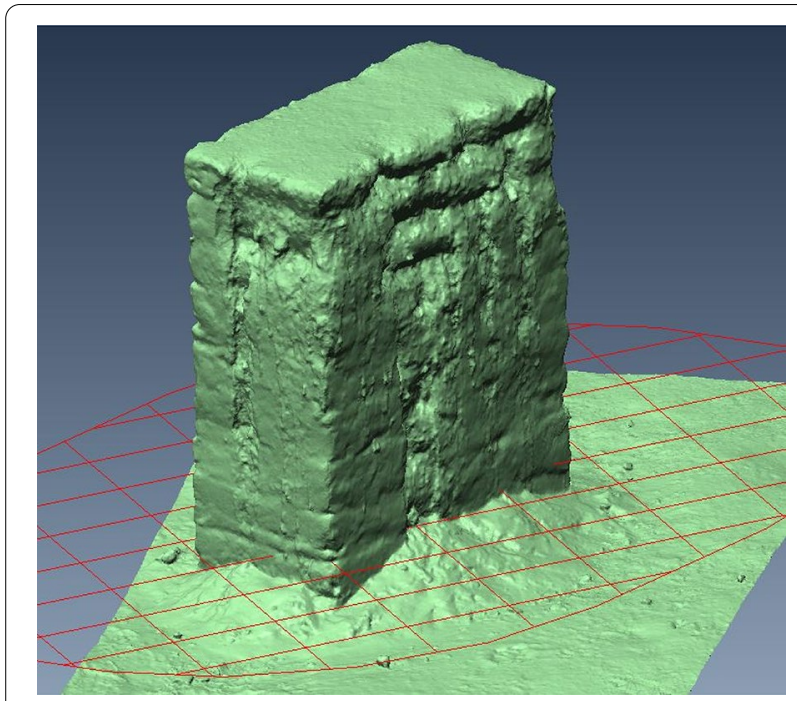

Fig. 5 Example of the three-dimensional mesh of an adobe test wall and exclusion plane 3-mm spatial resolution using Geomagic Wrap (v.11.0). A hole-filling operation was used to close the opening created by the reference-plane exclusion, resulting in a closed three-dimensional mesh from which volumes were computed (Fig. 5).

Affected surface area was defined as wall surfaces that exhibited deviation greater than or equal to $2 \mathrm{~mm}$ from the previous epoch. We used the Cloud-to-Mesh Distance tool in CloudCompare (v.2.11.2) to generate a scalar field, calculating a distance value to each mesh facet. Each wall model was then filtered to isolate facets representing distances exceeding the 2-mm error threshold. This threshold value was arrived at by observing measured deviations in the control walls between Epochs I and II and Epochs III and IV. Comparison of Epochs I and IV was not used in threshold analysis due to the inadvertent weathering and damage to control-wall surfaces over the eight months of the project. As shown in Tables 4 and 5 a threshold of $2 \mathrm{~mm}$ yielded a detected change area of less than $1 \%$ on the non-treated control walls, indicating a robust confidence level. Analyses using thresholds under $2 \mathrm{~mm}$ resulted in a rapid increase in reported change detection on the control walls. Cavity depth was the maximum distance differential for each simulation. It was calculated using a nearly identical method to that used for affected surface area: extracting a maximum deviation from each wall model, rather than a surfacearea measurement.

\section{Moisture sensors}

Internal wall moisture was measured with METER Group EC-5 sensors paired with an Em50 data logger (METER,
Table 4 Affected surface area metrics for epochs I and II

\begin{tabular}{|c|c|c|c|}
\hline Wall ID & $\begin{array}{l}\text { Initial surface } \\
\text { area (Epoch I) }\end{array}$ & $\begin{array}{l}\text { Area exceeding } 2 \mathrm{~mm} \\
\text { surface deviation }(\mathrm{cm})\end{array}$ & $\begin{array}{l}\% \text { surface } \\
\text { area change }\end{array}$ \\
\hline A & 2.39037 & 6348.97 & 26.56 \\
\hline $\mathrm{B}^{*}$ & 2.44042 & $7.18 \mathrm{E}-01$ & 0.00 \\
\hline C & 2.56427 & 1482.44 & 5.78 \\
\hline$D^{*}$ & 2.34887 & 13.0351 & 0.06 \\
\hline$E$ & 2.13564 & 7683.96 & 35.98 \\
\hline $\mathrm{F}$ & 2.27458 & 5957.49 & 26.19 \\
\hline G & 2.3399 & 7177.99 & 30.68 \\
\hline $\mathrm{H}$ & 2.34361 & 7631.54 & 32.56 \\
\hline I & 2.34718 & 8594.06 & 36.61 \\
\hline$J^{*}$ & 2.41129 & 12.5374 & 0.05 \\
\hline K & 2.45843 & 6904.08 & 28.08 \\
\hline$L^{*}$ & 2.59524 & 18.4082 & 0.07 \\
\hline M & 2.66809 & 1290.42 & 4.84 \\
\hline $\mathrm{N}$ & 2.32143 & 9375.07 & 40.38 \\
\hline $\mathrm{O}$ & 2.0657 & 9221.69 & 44.64 \\
\hline$P$ & 2.5461 & 4723.43 & 18.55 \\
\hline Q & 2.3216 & 9063.29 & 39.04 \\
\hline $\mathrm{R}^{*}$ & 2.48753 & 28.8538 & 0.12 \\
\hline S & 2.66108 & 1718.29 & 6.46 \\
\hline $\mathrm{T}$ & 2.39898 & 1991.85 & 8.30 \\
\hline
\end{tabular}

${ }^{*}$ Bold rows indicate non-treated control walls

Table 5 Affected Surface Area Metrics for Epochs III and IV

\begin{tabular}{llcc}
\hline Wall ID & $\begin{array}{l}\text { Initial surface } \\
\text { area (epoch III) }\end{array}$ & $\begin{array}{l}\text { Area exceeding } \mathbf{2 ~} \mathbf{~ m m} \\
\text { surface deviation }(\mathbf{c m})\end{array}$ & $\begin{array}{c}\text { \% surface } \\
\text { area change }\end{array}$ \\
\hline A & 2.41526 & 1836.19 & 7.602453 \\
B* $^{*}$ & $\mathbf{2 . 3 4 5 9 3}$ & $\mathbf{6 . 6 5 6 3 2}$ & $\mathbf{0 . 0 2 8 3 7 4}$ \\
C & 2.56544 & 4798.69 & 18.70513 \\
D* & $\mathbf{2 . 3 4 9 9 9}$ & $\mathbf{3 6 . 6 7 6 9}$ & $\mathbf{0 . 1 5 6 0 7 3}$ \\
E & 2.19411 & 1706.54 & 7.777823 \\
F & 2.34617 & 2022.4 & 8.620006 \\
G & 2.32666 & 1994.67 & 8.573105 \\
H & 2.41107 & 1432.52 & 5.941428 \\
I & 2.32192 & 3161.16 & 13.61442 \\
J* & $\mathbf{2 . 4 0 7 8 4}$ & $\mathbf{1 0 . 4 9 2 8}$ & $\mathbf{0 . 0 4 3 5 7 8}$ \\
K & 2.3638 & 1129.64 & 4.778915 \\
L* & $\mathbf{2 . 5 8 0 8 6}$ & $\mathbf{4 0 . 0 1 1 2}$ & $\mathbf{0 . 1 5 5 0 3}$ \\
M & 2.67778 & 2459.61 & 9.185258 \\
N & 2.34988 & 2140.46 & 9.108806 \\
O & 2.04202 & 2084.6 & 10.20852 \\
P & 2.51366 & 5041.27 & 20.0555 \\
Q & 2.35092 & 2558.8 & 10.88425 \\
R* & $\mathbf{2 . 4 7 6 7 4}$ & $\mathbf{3 7 . 6 1 7 4}$ & $\mathbf{0 . 1 5 1 8 8 3}$ \\
S & 2.66901 & 2902.67 & 10.87546 \\
T & 2.39345 & 3789.16 & 15.83137 \\
\hline & & &
\end{tabular}

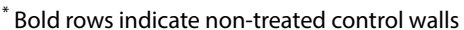


Pullman, WA, USA). The EC-5 measures volumetric water content (VWC) with a range of $0-1 \mathrm{~cm}^{3} \mathrm{~cm}^{-3}$ and an accuracy of $\pm 0.02 \mathrm{~cm}^{3} \mathrm{~cm}^{-3}$ [52]. VWC is the ratio of total water volume to the volume of the entire material, including soil, organic matter, air, and water. Saturation of the adobe block occurs at approximately 0.30 $\mathrm{cm}^{3} \mathrm{~cm}^{-3}$, the estimated total porosity (Table 1 ). VWC was sampled every two minutes during the high-intensity rainfall experiment and every ten minutes during the low-intensity experiment.

We accounted for temperature by first compensating the dielectric permittivity (DP) using the equation in Rosenbaum and others [53]. Then the compensated DP was converted to VWC using the equation in Malicki and others [54]. Mukhilisin and Saputra [55] determined that this equation modeled the DP/VWC relationship most accurately compared to ten other models.

Net change of VWC ( $\Delta \theta \mathrm{VWC})$ was derived as the difference between the VWC immediately before the start of each treatment and the maximum VWC recorded after the treatment began. Drying time was determined as the time from the maximum VWC recorded after the respective treatment began to when VWC decreased to the same level as at the start of each treatment.

\section{Data analysis}

For the high-intensity rainfall experiment, we computed linear, quadratic, cubic, and quartic regression models using the ordinary least squares method for the five metrics (material loss, volume loss, affected surface area, maximum cavity depth, and $\Delta \theta \mathrm{VWC}$ ) by rainfall intensity, and chose the best-fit model for each based on Akaike's information criterion (AIC). We also computed a linear model of the five metrics by treatment (control, 1-year storm, 25-year storm, 100-year storm). Metrics that demonstrated homogeneity of variance were analyzed using one-way analysis of variance (ANOVA) and Tukey's post-hoc test. Metrics with unequal variance were analyzed using White-corrected ANOVA and the Dunnett T3 post-hoc test.

For the low-intensity rainfall experiment, we computed a linear, mixed-effect model of the five metrics by treatment (control, 1-event or 2-event) as the fixed effect, with the erosion metrics from the high-intensity rainfall experiment as random effects to account for the varying condition of each wall at the start of the low-intensity experiments. The model with the lowest AIC was chosen for analysis. Each model was analyzed using ANOVA and Tukey's post-hoc test. Metrics that affected drying time were also calculated in this way. We computed linear and quadratic regression models for drying time using $\Delta \theta \mathrm{VWC}$ and erosion metrics for both the high- and low-intensity rainfall simulations and chose the best-fit model for each based on the AIC.

We used RStudio (v.3.6.3) for the analyses: stats (v.3.6.2) for linear models, rcompanion (v.2.3.25) for linear model comparison, nlme (v.3.1-144) for generalized linear mixed and general least squares models, emmeans (v.1.4.5) to estimate marginal means, car (v.3.0-7) for type-II ANOVA (F-tests for linear models, Wald chisquare for linear mixed-effect), multcomp (v.1.4-12) to generate group letters of Tukey pairwise comparisons, PMCMRplus (v.1.4.4) for Dunnett T3 pairwise comparisons, and multcompview (v.0.1-8) to generate group letters.

\section{Results}

\section{High-intensity rainfall experiment}

Degradation metrics demonstrated that significantly different material loss (\%) and affected surface area resulted from each high-intensity treatment (Tables 6, 7, Fig. 6a, b). The 100-year storm caused the greatest material losses, generating mean wall material loss of $5.64 \%$ and mean affected surface area of $8790 \mathrm{~cm}^{2}$. These changes represented substantial damage (including splashsheet, detachment, rilling, and mass wasting) to bare adobe from a 30-min rain event. The regression models for all three wall-degradation metrics (material loss, affected surface area, and cavity depth) were significant, with $R^{2} \geq 0.93$. The lines of best-fit for material loss and affected surface area showed that erosion of the adobe walls increased with rain intensity, at an increasing rate of change (Fig. 7).

Maximum cavity depth also increased with rain intensity (Fig. 6c), but the line of best-fit leveled off near the 100-year intensity level $\left(10.6 \mathrm{~cm} \mathrm{~h}^{-1}\right)$ (Fig. 7c). Similarly, maximum cavity depth was largest for walls receiving the 100-year treatment, with a mean of $9.23 \mathrm{~cm}$. However, the pairwise comparisons indicated that the 100-year and 25-year treatments were not statistically different (Fig. 6c). Overall, significant damage occurred to the bare adobe walls in all metrics. The increasing rate of change for material loss and affected surface area is concerning, given climate-change predictions.

Rain intensity was not a strong predictor for $\Delta \theta \mathrm{VWC}$ in the high-intensity experiment (Fig. 7d). The $\Delta \theta \mathrm{VWC}$ was slightly higher in the adobe walls that received rainfall treatments compared to the control walls. However, the F-test (for variability between the group means) indicated that none of the treatments were significantly different, and post-hoc tests were not conducted (Fig. 6d, Table 7). The regression equation showed a significant, marginally increasing relationship between rain intensity and $\Delta \theta \mathrm{VWC}$, but the results included high variability with outlier data points, resulting in a low $R^{2}$ of 


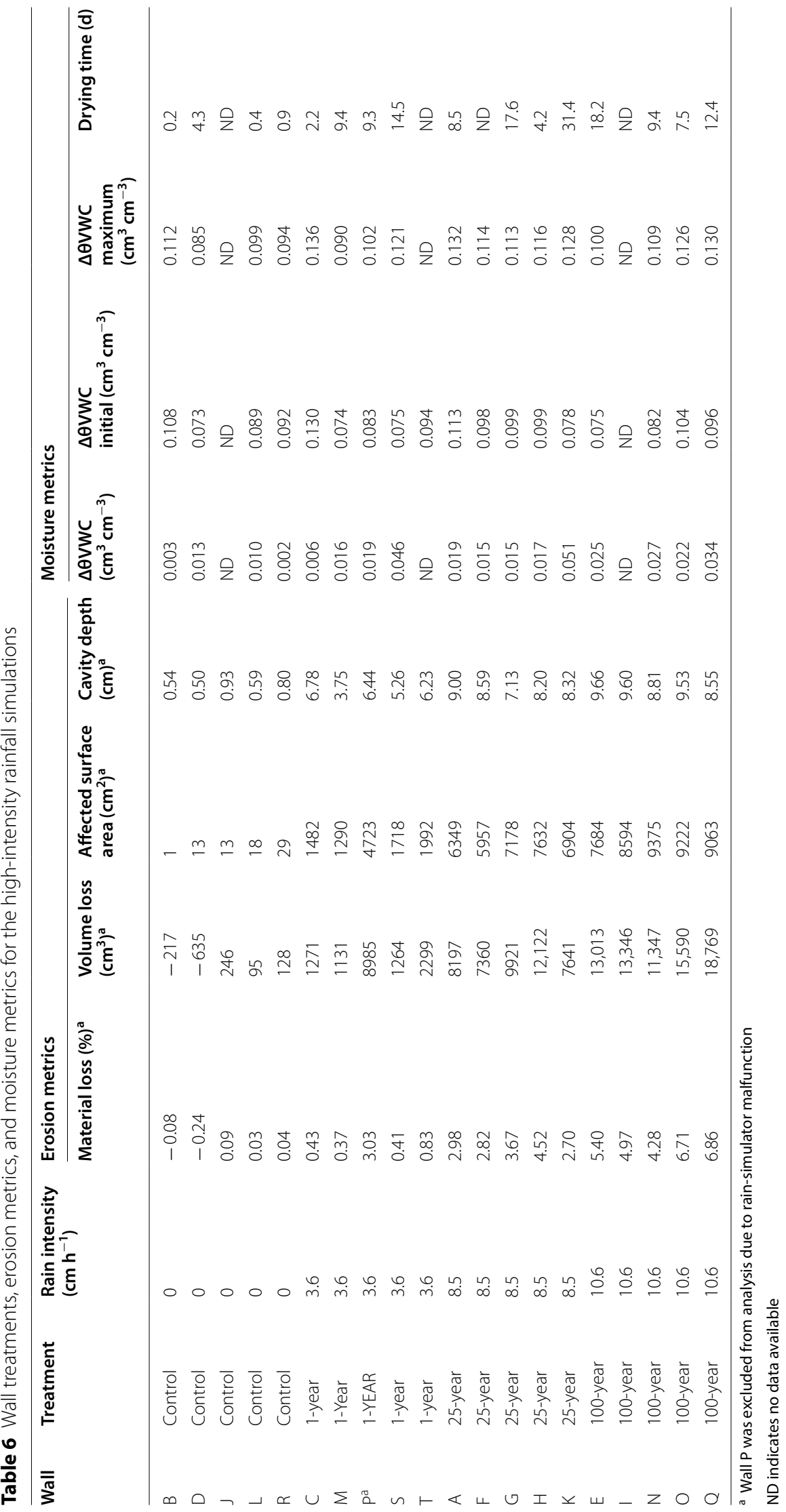


Table 7 ANOVA results for the high-intensity rainfall simulations

\begin{tabular}{llllll}
\hline Parameter & $\begin{array}{l}\text { Material } \\
\text { Loss }(\%)^{\mathbf{a}}\end{array}$ & $\begin{array}{l}\text { Volume } \\
\text { Loss } \\
\left(\mathbf{c m}^{\mathbf{3}}\right)^{\mathbf{a}}\end{array}$ & $\begin{array}{l}\text { Affected } \\
\text { Surface } \\
\text { Area } \\
\left(\mathbf{c m}^{2}\right)^{\mathbf{a}}\end{array}$ & $\begin{array}{l}\text { Cavity } \\
\text { Depth } \\
(\mathbf{c m})^{\mathbf{a}}\end{array}$ & $\begin{array}{l}\Delta \theta \text { VWC } \\
\left(\mathbf{c m}^{\mathbf{3}} \mathbf{c m}^{-\mathbf{3}}\right)\end{array}$ \\
\hline F-test & 60.5 & 66.2 & 323 & 448 & 1.91 \\
p-value & $<0.001$ & $<0.001$ & $<0.001$ & $<0.001$ & 0.182
\end{tabular}

${ }^{a}$ Metrics had unequal variance; White-corrected analysis of variance used
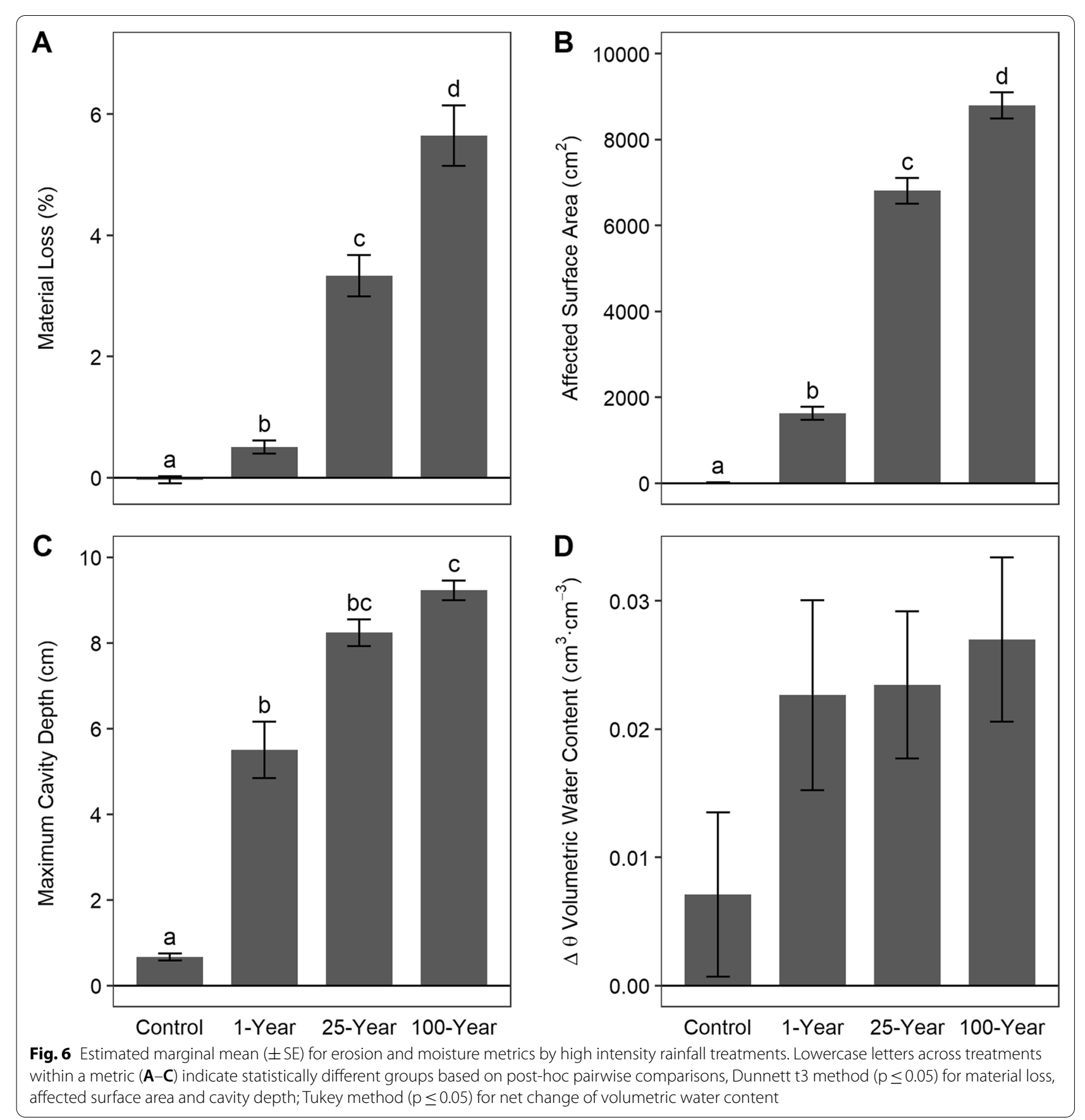

0.26 (Fig. 7d). The outliers were likely related to the colocation of deep cavities near the VWC sensors on some walls, causing increased internal moisture near the sensor. For example, during the high-intensity simulation, Wall $S$ developed a rill near the EC-5 sensor and had the second-highest $\Delta \theta \mathrm{VWC}$ results (Fig. 8, Table 6). Removing the outliers increased the $R^{2}$ to 0.77 . The ANOVA for this subset of $\triangle \theta \mathrm{VWC}$ rejected the null hypothesis. The pairwise comparisons showed the $\Delta \theta \mathrm{VWC}$ for the 

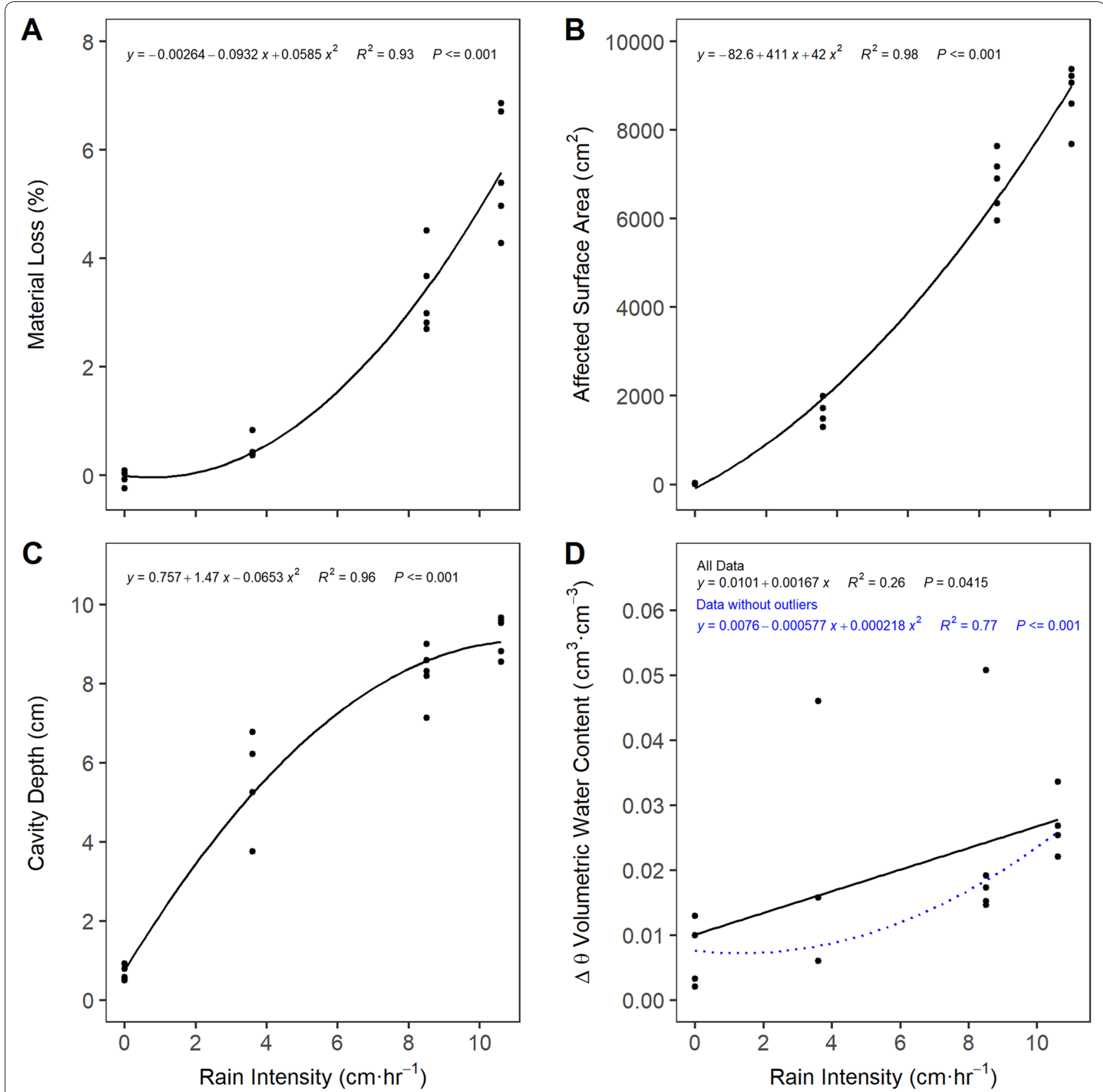

Fig. 7 Line of best-fit for erosion and moisture metrics with rain intensity. Blue indicates the best-fit line and regression equation for a subset of the data

100-year treatment was statistically greater than for the other three treatments.

\section{Low-intensity rainfall experiment}

In the low-intensity rainfall experiment, affected surface area, maximum cavity depth, and $\Delta \theta V W C$ were significantly greater in both the 1-event and 2-event treatments than in the control (Tables 8, 9, Fig. 9b-d). The 1-event and 2-event treatments were statistically comparable for these three metrics $(p=0.440,0.366$, and 0.776 , respectively). However, the estimated marginal means were lower in the 2-event treatment. This is likely because drying occurred during the 48-h hiatus between rain events in the 2-event treatment. Material loss was statistically the same for all three treatments. Each treatment included positive and negative material-loss values, which may indicate expansion of the walls or errors in the scanning process or analysis. 


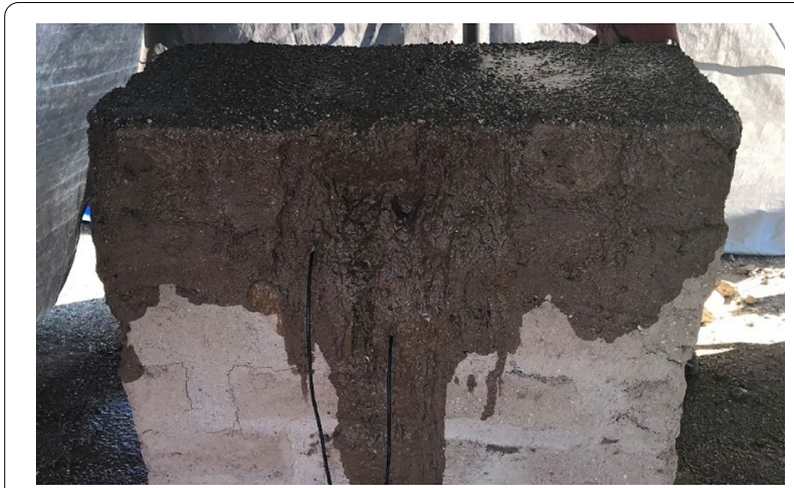

Fig. 8 Wall S with erosion near the EC-5 sensor
The affected surface area resulting from the high-intensity experiment demonstrated a significant fixed effect for both material loss and affected surface area in the lowintensity experiment ( $p=0.0456$ and 0.003 , respectively). The relationship is slightly inverse, indicating that walls with greater affected surface areas following the highintensity treatments were associated with marginally less material loss and affected surface area resulting from the low-intensity treatments. The condition of the walls prior to the low-intensity treatments was not a significant variable for maximum cavity depth and $\Delta \theta \mathrm{VWC}$.

Net change in VWC was positively correlated with several erosion metrics, both individual and in combination,

Table 8 Wall treatments, erosion metrics, and moisture metrics for the low-intensity rainfall simulations

\begin{tabular}{|c|c|c|c|c|c|c|c|c|c|}
\hline Wall & Treatment & $\begin{array}{l}\text { Material loss } \\
(\%)\end{array}$ & $\begin{array}{l}\text { Volume loss } \\
\left(\mathrm{cm}^{3}\right)\end{array}$ & $\begin{array}{l}\text { Affected } \\
\text { surface area } \\
\left(\mathrm{cm}^{2}\right)\end{array}$ & $\begin{array}{l}\text { Max cavity } \\
\text { depth }(\mathrm{cm})\end{array}$ & $\begin{array}{l}\Delta \theta V W C \\
\left(\mathrm{~cm}^{3} \mathrm{~cm}^{-3}\right)\end{array}$ & $\begin{array}{l}\text { VWC } \\
\text { starting } \\
\left(\mathrm{cm}^{3} \mathrm{~cm}^{-3}\right)\end{array}$ & $\begin{array}{l}\text { VWC } \\
\text { maximum } \\
\left(\mathrm{cm}^{3} \mathrm{~cm}^{-3}\right)\end{array}$ & Drying time (d) \\
\hline B & Control & -0.09 & -251 & 7 & 0.42 & 0.012 & 0.081 & 0.093 & 0.4 \\
\hline D & Control & 0.31 & 830 & 37 & 2.19 & 0.005 & 0.044 & 0.049 & 0.4 \\
\hline J & Control & 0.91 & 2551 & 10 & 0.93 & ND & ND & ND & ND \\
\hline L & Control & -0.37 & -1115 & 40 & 0.93 & 0.008 & 0.055 & 0.063 & 0.3 \\
\hline$R$ & Control & -0.15 & -426 & 38 & 1.43 & 0.008 & 0.052 & 0.060 & 0.0 \\
\hline A & 1-event & -0.26 & -694 & 1836 & 4.47 & 0.119 & 0.079 & 0.198 & 25.4 \\
\hline C & 1-event & -0.48 & -1422 & 4799 & 3.06 & 0.182 & 0.056 & 0.238 & 48.2 \\
\hline F & 1-event & -0.03 & -81 & 2022 & 3.16 & 0.108 & 0.063 & 0.171 & 29.8 \\
\hline I & 1-event & 2.24 & 5673 & 3161 & 4.14 & 0.087 & 0.053 & 0.140 & ND \\
\hline M & 1-event & 1.10 & 3394 & 2460 & 4.77 & 0.099 & 0.047 & 0.147 & 28.0 \\
\hline $\mathrm{N}$ & 1-event & 1.25 & 3171 & 2140 & 3.27 & 0.149 & 0.044 & 0.193 & 13.1 \\
\hline $\mathrm{P}^{\mathrm{a}}$ & 1-event & 2.52 & 7307 & 5041 & 11.45 & 0.140 & 0.056 & 0.196 & 24.0 \\
\hline Q & 1-event & 0.42 & 1072 & 2559 & 3.94 & 0.153 & 0.061 & 0.214 & 47.9 \\
\hline E & 2-event & -0.02 & -58 & 1707 & 3.87 & 0.106 & 0.043 & 0.149 & 34.9 \\
\hline G & 2-event & 0.27 & 668 & 1995 & 3.92 & 0.064 & 0.073 & 0.137 & 24.9 \\
\hline $\mathrm{H}$ & 2-event & 0.99 & 2615 & 1433 & 2.25 & 0.136 & 0.047 & 0.183 & 20.2 \\
\hline K & 2-event & 0.58 & 1528 & 1130 & 3.55 & 0.131 & 0.049 & 0.180 & 24.3 \\
\hline O & 2-event & 1.66 & 3604 & 2085 & 2.82 & 0.119 & 0.072 & 0.191 & 35.7 \\
\hline S & 2-event & 0.20 & 607 & 2903 & 3.99 & 0.133 & 0.041 & 0.174 & 20.4 \\
\hline $\mathrm{T}$ & 2-event & 0.39 & 1057 & 3789 & 2.89 & 0.138 & 0.062 & 0.201 & 41.1 \\
\hline
\end{tabular}

${ }^{a}$ Wall $\mathrm{P}$ was excluded from analysis due to rain-simulator malfunction

ND indicates no data available

Table 9 ANOVA results for the low-intensity rainfall simulations

\begin{tabular}{|c|c|c|c|c|c|}
\hline Parameter & Material Loss (\%) & Volume Loss $\left(\mathrm{cm}^{3}\right)$ & $\begin{array}{l}\text { Affected Surface } \\
\text { Area }\left(\mathrm{cm}^{2}\right)\end{array}$ & $\begin{array}{l}\text { Max Cavity Depth } \\
\text { (cm) }\end{array}$ & $\Delta \theta V W C\left(\mathrm{~cm}^{3} \mathrm{~cm}^{-3}\right)$ \\
\hline $\begin{array}{l}\text { Random effect (from high- } \\
\text { intensity experiment) }\end{array}$ & Affected surface area & Affected surface area & Affected surface area & Cavity depth & Affected surface area \\
\hline Wald test & 1.67 & 1.47 & 31.9 & 48.8 & 55.5 \\
\hline$p$-value & 0.433 & 0.478 & $<0.001$ & $<0.001$ & $<0.001$ \\
\hline
\end{tabular}



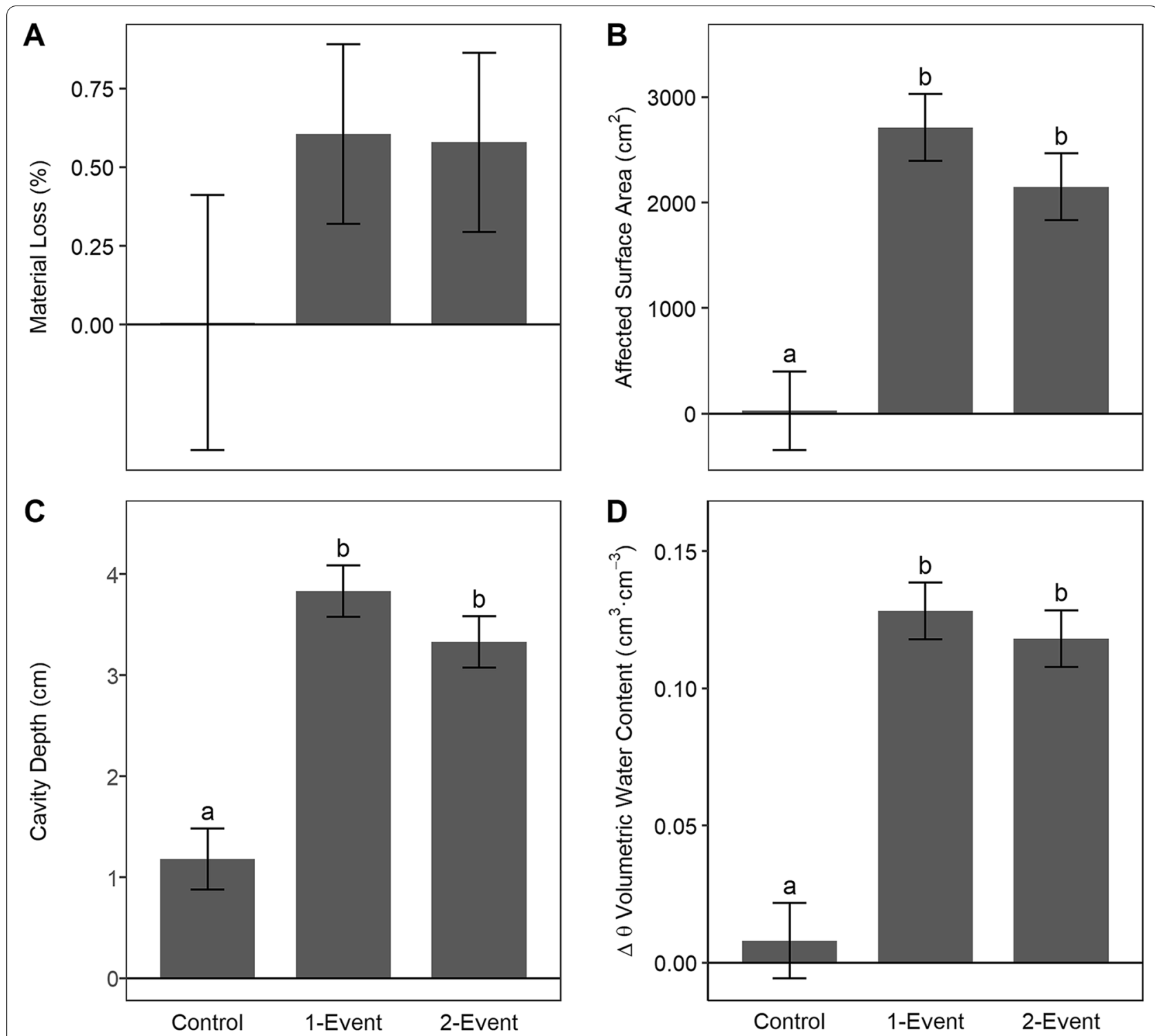

Fig. 9 Panels $\mathbf{A}-\mathbf{D}$ show estimated marginal mean $( \pm S E)$ for erosion and moisture metrics from low-intensity rainfall treatments. Lowercase letters across treatments within a metric (B-D) indicate statistically different groups based on post-hoc pairwise comparisons, Tukey method ( $p \leq 0.05$ )

from both the high- and low-intensity simulations. For both experiments, the regression of $\triangle \theta \mathrm{VWC}$ with affected surface area was the best-fit model $\left(R^{2}=0.765\right.$, $p \leq 0.001)$. Increased surface area may have increased infiltration and VWC in the walls.

\section{Drying time}

Two-thirds of the drying-time variation (see Table 8) was explained by the $\Delta \theta$ VWC (Fig. 10). The significant regression equations of drying time based on $\Delta \theta \mathrm{VWC}$ showed that the walls dried twice as quickly following the low-intensity treatments $\left(2.24 \mathrm{~d}\right.$ per $0.01 \mathrm{~cm}^{3} \mathrm{~cm}^{-3}$
$\Delta \mathrm{VWC}$ ) as the high-intensity treatments (4.84 d per 0.01 $\mathrm{cm}^{3} \mathrm{~cm}^{-3} \Delta$ VWC). The difference in drying rate was likely related to the uniformity of moisture in the wall after each simulation, and ambient air temperature during the drying period. The low-intensity, long-duration treatments likely caused more uniform wetting of the walls, while the high-intensity, short-duration treatments likely resulted in a gradient of higher moisture in the outer portions of the wall adjacent to the surface, decreasing toward the center of the wall, where the VWC sensor was located. This is consistent with visual observations of the wall surface during the high-intensity 


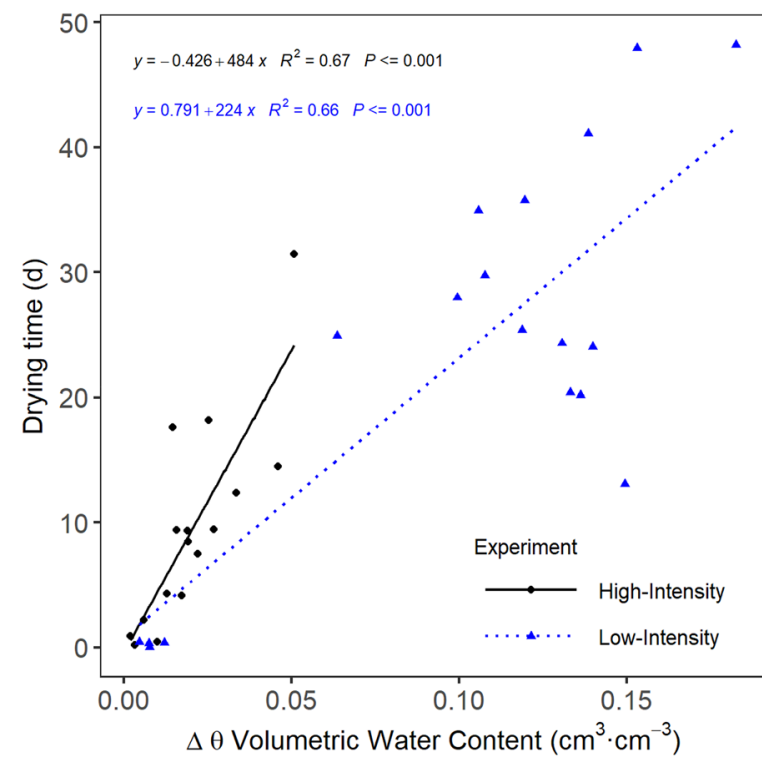

Fig. 10 Lines of best-fit for net change of volumetric water content and drying time for the high- and low- intensity experiments

simulation, and the relatively low $\Delta \theta$ VWC. In addition, the high-intensity simulation occurred in fall, when the average temperature and relative humidity during the drying period were $12.2{ }^{\circ} \mathrm{C}$ and 0.40 , respectively. The low-intensity simulation occurred in late spring. Drying continued into summer, when average temperature was higher $\left(29.8^{\circ} \mathrm{C}\right)$, and relative humidity lower $(0.23)$, contributing to a higher evaporation rate. Even under these warm, dry conditions, the wettest wall $(\Delta \theta \mathrm{VWC}=0.182$ $\mathrm{cm}^{3} \mathrm{~cm}^{-3}$ ) took over 48 days to fully dry to the starting VWC (Table 8). Linear regression models containing wall-degradation metrics as additional independent variables individually and in combination did not provide better-fit models.

\section{Discussion}

As noted, recent anecdotal evidence of increased intensity in monsoon events led us to conduct this study. The relationship between rainfall and test walls indicated a nearly exponential increase in wall degradation with increasing rainfall intensity (see Fig. 7). This included an interaction between rainfall intensity/duration and several erosion processes (e.g., splash-sheet, detachment, rilling, and mass wasting). Observations of the progression of erosion processes during high-intensity rainfall simulations provide some insight about the hydrologic mechanisms causing this relationship. Below are the stages of deterioration we observed during high-intensity simulations:
1. At the onset of rainfall simulations, erosion was likely driven by raindrop impacts detaching particles from the wall surface. Initially high infiltration rates [56] appeared to limit runoff and associated erosion processes.

2. As rainfall continued, we observed sediment winnowing from splash-sheet processes [57-59], resulting in the top of the wall becoming armored with larger particle sizes. This likely mitigated material loss as the surface became less erodible [60].

3. As infiltration rates waned below the applied precipitation rate, we noted ponding on top of the walls. Runoff began to be routed along the sides of walls, creating areas more vulnerable to rain splash detachment and heightened sheer stress from concentrated flow [57-59]. These vulnerable areas, typically near mortar joints, began to scour, creating incised flow paths beginning at the top of the wall or cavities immediately below the top row of blocks (Fig. 8).

4. Rills beginning at the top of the wall continued to incise and/or expand laterally over the duration of the simulation. In areas where a cavity developed, overlying blocks gradually became more saturated as infiltration continued. Once the sheer strength of the block was sufficiently decreased by increasing pore pressure, the overburden collapsed in a mass-wasting event [61].

Hydrological mechanisms explain the large increase in material loss found at intensities greater than or equal to $8.5 \mathrm{~cm} \mathrm{~h}^{-1}$. Importantly, the mass wasting observed in this study requires the interaction of infiltration and erosion processes [61]. This interaction would not be captured by immersion, absorption, and erodibility tests [23]. Another possible contributor to the high soil loss is the "new-old" state of the walls. The condition of the walls at the start of each experiment may have affected the erosion processes. For example, in the high-intensity experiment, the newly constructed walls had relatively flat tops, leading to ponding on the top of the wall and then runoff, which could have caused greater erosion compared to the weathered walls in the low-intensity experiment.

Both rain amount and intensity are important to understanding how a rain event affects bare adobe walls. For example, the low-intensity 1 -event treatment produced over twice the rainfall (volume) but less than one-third of the intensity of the high-intensity 1-year treatment (Table 10). Yet the results for material loss and affected surface area were similar between the two treatments, while cavity depth was greater in the high-intensity treatment. This suggests that rilling was a less-dominant source of erosion under the lower-intensity rainfall. All erosion metrics were greater in the high-intensity 25 -year 
Table 10 Estimated marginal means of wall degradation and moisture metrics for select treatments

\begin{tabular}{|c|c|c|c|}
\hline Metric & $\begin{array}{l}\text { Low-intensity, 1-event }(3.9 \mathrm{~cm} \text { at } \\
\left.1.0 \mathrm{~cm} \mathrm{~h}^{-1}\right)\end{array}$ & $\begin{array}{l}\text { High-intensity, 1-year }(1.8 \mathrm{~cm} \text { at } \\
\left.3.6 \mathrm{~cm} \mathrm{~h}^{-1}\right)\end{array}$ & $\begin{array}{l}\text { High-intensity, } \\
25 \text {-year }(4.2 \mathrm{~cm} \text { at } \\
\left.8.5 \mathrm{~cm} \mathrm{~h}^{-1}\right)\end{array}$ \\
\hline Material loss (\%) & 0.60 & 0.51 & 3.34 \\
\hline Affected surface area $\left(\mathrm{cm}^{2}\right)$ & 900 & 912 & 4670 \\
\hline Cavity depth (cm) & 3.83 & 5.51 & 8.25 \\
\hline$\Delta \theta$ volumetric water content $\left(\mathrm{cm}^{3} \mathrm{~cm}^{-3}\right)$ & 0.128 & 0.023 & 0.023 \\
\hline
\end{tabular}

treatment, which had a similar rain total, but at an intensity over eight times that of the low-intensity 1-event treatment.

While these results confirmed the suspicion that increased intensity in summer storms is creating more damage, the standard assumption that low-intensity, drenching rains create damage is still true. Managers of earthen architecture have long observed mass wasting following low-intensity, multi-day storm events. We did not observe this type of structural failure during the study. However, the substantial increases of interior moisture under the low-intensity treatments (with wall interiors remaining relatively dry after high-intensity treatments) provides evidence that internal saturation is likely a primary factor in large-scale failures. Simulating low-intensity rain over a duration beyond four hours may further support this inference. It will also be valuable to test how preservation methods change the infiltration and evaporation of precipitation.

\section{Conclusions}

\section{Information for decision-making}

The NPS mission requires resource managers "to conserve ... historic objects ... and to provide for the enjoyment of the same in such manner and by such means as will leave them unimpaired for the enjoyment of future generations" (16 U.S.C. 1-4). Balancing the preservation of earthen architecture and visitor enjoyment is a difficult task and throughout the history of the NPS, these two factors have led to a sense of overwhelming urgency: we must protect architecture now, before any more is lost. Couple that with limited testing on the mechanisms that cause structural damage and NPS cultural resource specialists are left to manage fragile resources with assumptions made from anecdotal observations.

The goal of this project was to provide some of those missing baseline data. This study demonstrated that bare adobe is highly vulnerable to degradation when exposed to ambient precipitation. Without the typically used preservation treatments, including caps and protective shelters, the adobe test walls experienced substantial impacts in response to simulated storm events. The high-intensity experiment confirmed the anecdotal observations of resource managers from across the US Southwest: there is a nearly exponential relationship between rain amount, rain intensity, and resource damage, as measured by material loss and affected surface area. The 100-year treatment $\left(10.6 \mathrm{~cm} \mathrm{~h}^{-1}\right)$ caused over $5 \%$ of the wall volume to erode, an astonishing amount for a 30-min rain event. However, the interior of walls, except proximate to deep cavities, remained relatively dry likely because the short duration of the simulated storms led to high runoff and limited infiltration. Thus, given the predicted increase in high-intensity storms, climate change is adding a new dimension of urgency to the NPS resource managers' suite of preservation challenges.

Interior wall moisture in the low-intensity treatments was substantially greater than the high-intensity treatments indicating deep water infiltration and less runoff under low-intensity, long-duration storms. While none of the walls collapsed, we suspect that a longer duration storm would cause additional infiltration, increasing internal moisture to a peak threshold where structural integrity is compromised. Multiple storms without adequate drying time could also progressively saturate the adobe. In this study gaps of up to two days did not contribute enough drying time for VWC in the low-intensity two-event treatment to be significantly different from the one-event treatment. Observed drying time after the low-intensity rain treatments of 13 to 48 days also indicates that multiple rain events with a week or more drying time, could still have compounding effects on internal moisture.

Earthen architectural sites respond to weather events in different ways. A site's age, location and treatment history are just some of the many factors that might impact how it deteriorates over time. The results presented here provide necessary baseline information on how bare adobe is affected by rain events and will help park managers to make informed decisions about the protection and preservation of adobe architecture. This study also creates a useful starting point for developing expectations for future impacts. 


\section{Next step: test additives with the same experiments}

This project, and specifically the partnership between the NPS and the ARS, provided the necessary components to understand baseline issues, be proactive, and test anecdotal evidence. Continuing this partnership is essential, because the research described in this article was just a first step. More testing is needed to fully explore the details presented here. This and future data will be used to construct a matrix of wall degradation based on total rainfall and intensity. This information will allow NPS resource managers to better preserve earthen architecture year-round.

This study suggests that large rainfall totals, whether concentrated in a short high-intensity storm, or longer, low-intensity rainfall, can cause considerable damage to bare adobe; however, the mechanism of degradation varies. Building on the work presented here, we will examine which preservation methods protect adobe and prevent both infiltration and surficial damage from the impact of raindrops and runoff. Our next steps will be to revisit those amendment studies, especially Fort Selden, and to test the best performing amendments with similar treatments to those reported here. Determining the durability of the materials, their resistance to crack formation and deterioration, and how amendments or caps change the infiltration and evaporation of precipitation, will be essential to the continued preservation of earthen architecture across the US Southwest. This data will be invaluable to resource managers as they look at their cyclic maintenance needs and prepare for future extreme weather events.

\section{Abbreviations}

AIC: Akaike's information criterion; ANOVA: Analysis of variance; ARS: US Department of Agriculture's Agriculture Research Service; $\triangle \theta V W C$ : Net change of Volumetric Water Content; DP: Dielectric permittivity; DRLC: NPS Sonoran Desert Network's Desert Research Learning Center; LiDAR: Laser imaging, detection, and ranging; NPS: US Department of Interior's National Park Service; NHP: National Historical Park; US: United States; VWC: Volumetric water content.

\footnotetext{
Acknowledgements

This project is a testament to the power of collaboration. Partnerships between the National Park Service's Southern Arizona Office (SOAR), the NPS Sonoran Desert Network (SODN), Tumacácori National Historical Park, and the US Department of Agriculture's Agricultural Research Service made this project a success. The authors would also like to thank the many people who aided the project along the way. Earthen architecture preservationists David Yubeta, Chris Schrager, and Ray Madril led the wall-building trainings, and also gave their sage advice to the project. Andrew Hubbard of SODN/DRLC was instrumental in logistics and research design. Alice Wondrak Biel of SODN also assisted with project outreach and the development of the manuscript.

The authors also thank Dr. Fred Pierson of the USDA-ARS Northwest Watershed Research Center, Boise, Idaho, for use of rainfall simulators applied in this study. Further, Cheryl McIntyre (SODN) aided with the statistical analysis, while Iraida Rodriguez (SOAR) performed some LiDAR data collection. Their time and expertise is much appreciated. We also wish to thank the National Park Service Albright-Wirth Grant Program and the National Center for Preservation Technology and Training as well as Lauren Meyer and the National Park
}

Service Vanishing Treasures Program.The USDA is an equal opportunity provider and employer. Mention of a proprietary product does not constitute endorsement by USDA and does not imply its approval to the exclusion of the other products that may also be suitable.

\section{Authors' contributions}

$\mathrm{SH}$ contributed to the development of project methodology, the construction of adobe test walls, the collection and analysis of project data and was a major contributing writer. KR contributed to the development of project methodology, the construction of adobe test walls, the installation of moisture sensors and was a major contributor to the statistical analysis as well as the writing and revision of the manuscript. JW contributed to the development of project methodology, was a major contributor to the implementation of rain simulations and assisted with the analysis of project data and the writing of the manuscript. JJ contributed to the development of project methodology was a major contributor to the implementation of rain simulations and assisted with the analysis of project data and the writing of the manuscript. JD assisted with the development of project methodology was a major contributor to the implementation of Lidar scanning and the analysis of spatial data as well as assisting with writing of the manuscript. MG contributed to the development of project methodology and was a major contributor to the writing and revision of the manuscript. All authors read and approved the final manuscript.

\section{Funding}

This work was funded by the National Park Service's Albright-Wirth Grant Program (2018) and the National Center for Preservation Technology and Training, Preservation Technology and Training Grants program (P18AS00006).

\section{Availability of data and materials}

The data will be available upon request.

\section{Declarations}

\section{Competing interests}

As authors, we declare that we have no conflicts of interest to disclose.

\section{Author details}

${ }^{1}$ National Park Service, Southern Arizona Office, 3636 North Central Avenue, Suite 410, Phoenix, AZ 85012, USA. ${ }^{2}$ US Department of Agriculture, Agriculture Research Service, Southwest Watershed Research Center, 2000 East Allen Road, Tucson, AZ 85719, USA. ${ }^{3}$ School of Natural Resources and the Environment, The University of Arizona, Environment and Natural Resources 2, 1064 East Lowell Street, Tucson, AZ 85721, USA.

Received: 3 August 2021 Accepted: 16 October 2021

Published online: 04 November 2021

\section{References}

1. Day RW. Performance of historic adobe structure. J Perform Constr Facil. 1993;7(3):164-9. https://doi.org/10.1061/(ASCE)0887-3828(1993)7:3(164).

2. Shamir E, Tapia-Villaseñor EM, Cruz-Ayala M-B, Megdal SB. A Review of climate change impacts on the USA-Mexico transboundary Santa Cruz River Basin. Water. 2021;13:1390. https://doi.org/10.3390/w13101390.

3. Demaria EMC, Hazenberg P, Scott RL, Meles MB, Nichols M, Goodrich D. Intensification of the North American Monsoon rainfall as observed from a long-term high-density gauge network. Geophys Res Lett. 2019;46:6839-47. https://doi.org/10.1029/2019GL082461.

4. Janssen E, Wuebbles DJ, Kunkel KE, Olsen SC, Goodman A. Observationaland model-based trends and projections of extreme precipitation over the contiguous United States. Earths Future. 2014;2:99-113. https://doi. org/10.1002/2013EF000185

5. Borodina A, Fischer EM, Knutti R. Models are likely to underestimate increase in heavy rainfall in the extratropical regions with high rainfall intensity. Geophys Res Lett. 2017;2017(44):7401-9. https://doi.org/10. 1002/2017GL074530.

6. Tripathi OP, Dominguez F. Effects of spatial resolution in the simulation of daily and subdaily precipitation in the southwestern US. J Geophys Res Atmos. 2013;118:7591-605. https://doi.org/10.1002/jgrd.50590. 
7. Easterling DR, Kunkel KE, Arnold JR, Knutson T, LeGrande AN, Leung LR, et al. Precipitation change in the United States. In: Wuebbles DJ, Fahey DW, Hibbard KA, Dokken DJ, Stewart BC, Maycock TK, editors., et al., Climate science special report: fourth national climate assessment, vol. I. Washington: U.S. Global Change Research Program; 2017. https://doi.org/ 10.7930/JOH993CC.

8. Wang B, Biasutti M, Byrne MP, Castro C, Chang C, Cook K, Fu R, Grimm AM, Ha K, Hendon H. Climate change assessment. Bull Am Meteorol Soc. 2021:102:E1-19. https://doi.org/10.1175/BAMS-D-19-0335.1.

9. Pascale S, Carvalho LMV, Adams DK, Castro CL, Cavalcanti IFA. Current and future variations of the monsoons of the Americas in a warming climate. Curr Clim Chang Rep. 2019;5:125-44. https://doi.org/10.1007/ s40641-019-00135-w.

10. Luong TM, Castro CL, Chang H, Lahmers T, Adams DK, Ochoa-Moya CA. The more extreme nature of north American monsoon precipitation in the southwestern United States as revealed by a historical climatology of simulated severe weather events. J Appl Meteor Clim. 2017;56:2509-29. https://doi.org/10.1175/JAMC-D-16-0358.1.

11. Bukovsky MS, Carrillo CM, Gochis DJ, Hammerling DM, McCrary RR, Mearns LO. Toward assessing NARCCAP regional climate model credibility for the North American monsoon: future climate simulations. J Clim. 2015;28:6707-28. https://doi.org/10.1175/JCLI-D-14-00695.1.

12. Collins M, Knutti R, Arblaster J, Dufresne JL, Fichefet T, Friedlingstein P, et al. Long-term climate change: projections, commitments and irreversibility. In: Stocker TF, Qin D, Plattner GK, Tignor M, Allen SK, Boschung J, et al. editors. Climate change 2013: the physical science basis. Contribution of working group I to the fifth assessment report of the intergovernmental panel on climate change. Cambridge: Cambridge University Press; 2013.

13. Wehner MF. Very extreme seasonal precipitation in the NARCCAP ensemble: model performance and projections. Clim Dyn. 2012;40:59-80. https://doi.org/10.1007/s00382-012-1393-1.

14. Kunkel KE, Karl TR, Brooks H, Kossin J, Lawrimore JH, Arndt D, et al. Monitoring and understanding trends in extreme storms: state of knowledge. Bull Amer Meteor Soc. 2013;94:499-514. https://doi.org/10.1175/ BAMS-D-11-00262.1.

15. Chang HI, Castro $\mathrm{CL}$, Carrillo CM, Dominguez F. The more extreme nature of U.S. warm season climate in the recent observational record and two "well-performing" dynamically downscaled CMIP3 models. J Geophys Res Atmos. 2015;120:8244-63. https://doi.org/10.1002/2015JD023333.

16. Shamir E, Megdal SB, Carrillo C, Castro CL, Chang H-I, Chief K, Corkhill FE, Eden S, Georgakakos KP, Nelson KM, et al. Climate change and water resources management in the Upper Santa Cruz River. Arizona J Hydrol. 2015;521:18-33. https://doi.org/10.1016/j.jhydrol.2014.11.062.

17. Cook BI, Ault TR, Smerdon JE. Unprecedented 21st century drought risk in the American Southwest and Central Plains. Sci Adv. 2015. https://doi. org/10.1126/sciadv.1400082.

18. Seager R, Neelin D, Simpson I, Liu H, Henderson N, Shaw S, Kushnir Y, Ting M. Dynamical and thermodynamical causes of large-scale changes in the hydrological cycle over North America in response to global warming. J Climate. 2014;27:7921-48. https://doi.org/10.1175/JCLI-D-14-00153.1.

19. Tomlinson EM, Kappel WD, Muhlestein GA, Hultstrand DM, Parzybok TW. Statewide probable maximum precipitation (PMP) study for Arizona. Applied Weather Associates, LLC; 2013.

20. Knutson TR, Sirutis JJ, Zhao M, Tuleya RE, Bender M, Vecchi GA, et al. Global projections of intense tropical cyclone activity for the late twentyfirst century from dynamical downscaling of CMIP5/RCP4.5 scenarios. J Clim. 2015;28:7203-24. https://doi.org/10.1175/JCLI-D-15-0129.1.

21. Knutson T, Camargo SJ, Chan JCL, Emanuel K, Ho C-H, Kossin J, Mohapatra M, Satoh M, Sugi M, Walsh K, et al. Tropical cyclones and climate change assessment: part II: projected response to anthropogenic warming. Bull Am Meteorol Soc. 2020;101:E303-22. https://doi.org/10.1175/ BAMS-D-18-0194.1.

22. Heredia Zavoni EA, Bariola Bernales JJ, Neumann JV, Mehta PK. Improving the moisture resistance of adobe structures. Mater Struct. 1988;21:21321. https://doi.org/10.1007/BF02473058.

23. Beckett $C T$, Jaquin PA, Morel JC. Weathering the storm: a framework to assess the resistance of earthen structures to water damage. Constr Build Mater. 2020;242:118098.
24. Rempel AW, Rempel AR. Frost resilience of stabilized earth building materials. Geosciences. 2019;9(8):328. https://doi.org/10.3390/geoscience s9080328.

25. Richards J, Zhao G, Zhang H, Viles H. A controlled field experiment to investigate the deterioration of earthen heritage by wind and rain. Herit Sci. 2019;7(1):1-3. https://doi.org/10.1 186/s40494-019-0293-7.

26. Scott K, Moss J. Historic Preservation 2017: Pecos National Historical Park. National Park Service, Pecos National Historic Park. On file at the Sonoran Desert Network; 2017.

27. Oliver A, Getty Adobe Project. Fort Selden adobe test wall project: phase I: final report. Getty Cons Inst and Mus of NM; 2000. http://hdl.handle.net/ 10020/gci_pubs/fort_selden_project. Accessed 30 June 2021.

28. Alam I, Naseer A, Shah AA. Economical stabilization of clay for earth buildings construction in rainy and flood prone areas. Constr Build Mater. 2015;77:154-9. https://doi.org/10.1016/j.conbuildmat.2014.12.046.

29. Millogo Y, Aubert JE, Séré AD, Fabbri A, Morel JC. Earth blocks stabilized by cow-dung. Mater Struct Const. 2016;2016(49):4583-94. https://doi. org/10.1617/s11527-016-0808-6.

30. Ren KB, Kagi DA. Upgrading the durability of mud bricks by impregnation. Build Environ. 1995. https://doi.org/10.1016/0360-1323(94)00056-X.

31. Erkal A, D'Ayala D, Sequeira L. Assessment of wind-driven rain impact, related surface erosion and surface strength reduction of historic building materials. Build Environ. 2012;57:336-48. https://doi.org/10.1016/j. buildenv.2012.05.004.

32. Kariyawasam KKGKD, Jayasinghe C. Cement stabilized rammed earth as a sustainable construction material. Constr Build Mater. 2016;105:519-27. https://doi.org/10.1016/j.conbuildmat.2015.12.189.

33. Kerali AG, Thomas TH. Simple durability test for cement stabilized blocks. Build Res Inf. 2004;32:140-5. https://doi.org/10.1080/096132103200014 8479.

34. Flanagan DC, Gilley JE, Franti TG. Water Erosion Prediction Project (WEPP): development history, model capabilities, and future enhancements. Trans ASABE. 2007:50:1603-12. https://doi.org/10.13031/2013.23968.

35. Polyakov V, Stone J, Holifield Collins C, Nearing MA, Paige G, Buono J, et al. Rainfall simulation experiments in the southwestern USA using the Walnut Gulch Rainfall Simulator. Earth Syst Sci. 2018;10:19-26. https://doi. org/10.5194/essd-10-19-2018.

36. Williams CJ, Pierson FB, Kormos PR, Al-Hamdan OZ, Johnson JC. Vegetation, ground cover, soil, rainfall simulation, and overland flow experiments before and after tree removal in woodland- encroached sagebrush steppe: the hydrology component of the Sagebrush Steppe Treatment Evaluation Project (SageSTEP). 2020. Earth Syst Sci Data. https://doi.org/ 10.5194/essd-12-1347-2020.

37. Ogunye $F O$, Boussabaine $H$. Development of a rainfall test rig as an aid in soil block weathering assessment. Constr Build Mater. 2002;16:173-80. https://doi.org/10.1016/S0950-0618(02)00010-7.

38. Hall MR. Assessing the environmental performance of stabilised rammed earth walls using a climatic simulation chamber. Build Environ. 2007;42:139-45. https://doi.org/10.1016/j.buildenv.2005.08.017.

39. Sharma V, Marwaha BM, Vinayak HK. Enhancing durability of adobe by natural reinforcement for propagating sustainable mud housing. Int J Sustain Built Environ. 2016;5:141-55. https://doi.org/10.1016/j.ijsbe.2016. 03.004 .

40. Geosystems Analysis Inc. Adobe and mortar materials physical and hydraulic testing. Tucson: Geosystems Analysis Inc; 2018.

41. ASTM International. ASTM D2937-17e2, standard test method for density of soil in place by the drive-cylinder method. ASTM International. West Conshohocken, PA; 2017. http://www.astm.org/cgi-bin/resolver.cgi? D2937-17e2. Accessed 30 June 2021.

42. ASTM International. ASTM D2434-68, standard test method for permeability of granular soils (constant head) (Withdrawn 2015). ASTM International. West Conshohocken, PA; 2006. http://www.astm.org/cgi-bin/resol ver.cgi?D2434-68(2006). Accessed 30 June 2021.

43. ASTM International. ASTM D4318-17e1, standard test methods for liquid limit, plastic limit, and plasticity index of soils. ASTM International. West Conshohocken, PA; 2017. http://www.astm.org/cgi-bin/resolver.cgi? D4318. Accessed 30 June 2021.

44. ASTM International. ASTM D 6913-17, standard test methods for particle-size distribution (gradation) of soils using sieve analysis. ASTM 
International. West Conshohocken, PA; 2017. http://www.astm.org/cgibin/resolver.cgi?D6913D6913M. Accessed 30 June 2021.

45. ASTM International. ASTM C136-14, standard test method for sieve analysis of fine and coarse aggregates. ASTM International. West Conshohocken, PA; 2017. http://www.astm.org/cgi-bin/resolver.cgi?C136C136M. Accessed 30 June 2021.

46. Bonnin GM, Martin D, Lin B, Parzybok T, Yekta M, Riley D. Precipitationfrequency atlas of the United States NOAA Atlas 14:1; version 5.0. Silver Spring: National Weather Service; 2011.

47. Meyer LD, Harmon WC. Multiple-intensity rainfall simulator for erosion research on row sideslopes. Trans ASAE. 1979;22:100-3. https://doi.org/ 10.13031/2013.34973.

48. Pierson FB, Moffet CA, Williams CJ, Hardegree SP, Clark PE. Prescribed-fire effects on rill and interrill runoff and erosion in a mountainous sagebrush landscape. Earth Surf Process Landforms. 2009;34:193-203. https://doi. org/10.1002/esp.1703.

49. Pierson FB, Robichaud PR, Moffet CA, Spaeth KE, Hardegree SP, Clark $P E$, et al. Fire effects on rangeland hydrology and erosion in a steep sagebrush-dominated landscape. Hydrol Process. 2008;22:2916-29.

50. van Dijk AIJ, Bruijnzeel L, Rosewell C. Rainfall intensity-kinetic energy relationships: a critical literature appraisal. J Hydrol. 2002;261:1-23. https:// doi.org/10.1016/S0022-1694(02)00020-3.

51. Surphaser. Surphaser 3D laser scanners. Redmond: Basis Software Inc; 2016.

52. METER Group. EC-5 manual. Pullman: METER Group Inc; 2018.

53. Rosenbaum U, Bogena H, Huisman J, Vrba J, Vereecken $H$. Correction of temperature and electrical conductivity effects on dielectric permittivity measurements with ECH2O sensors. Vadose Zone J. 2011;10:582-93. https://doi.org/10.2136/vzj2010.0083.
54. Malicki MA, Plagge R, Roth CH. Improving the calibration of dielectric TDR soil moisture determination taking into account the solid soil. Eur J Soil Sci. 1996:47:357-66.

55. Mukhlisin M, Saputra A. Performance evaluation of volumetric water content and relative permittivity models. ScientificWorldJournal. 2013. https://doi.org/10.1155/2013/421762.

56. Philip JR. The theory of infiltration: 4 . Sorptivity and algebraic infiltration equations. Soil Sci. 1957;84:257-64.

57. Bryan RB. Soil erodibility and processes of water erosion on hillslope. Geomorphology. 2000;32:385-415. https://doi.org/10.1016/S0169-555X(99) 00105-1.

58. Pierson FB, Williams CJ. Ecohydrologic impacts of rangeland fire on runoff and erosion: a literature synthesis. Fort Collins: General Technical Report RMRS-GTR-351; 2016

59. Selby MJ. Hillslope materials and processes. New York: Oxford University Press, Inc.; 1993

60. Nearing MA, Polyakov VO, Nichols MH, Hernandez M, Li L, Zhao Y, et al. Slope-velocity equilibrium and evolution of surface roughness on a stony hillslope. Hydrol Earth Syst Sci. 2017;21:3221-9. https://doi.org/10.5194/ hess-21-3221-2017.

61. Sidle RC, Pearce AJ, O'Laughlin CL. Hillslope stability and land use, vol. 11. Washington, DC: American Geophysical Union; 1985.

\section{Publisher's Note}

Springer Nature remains neutral with regard to jurisdictional claims in published maps and institutional affiliations.

\section{Submit your manuscript to a SpringerOpen ${ }^{\circ}$ journal and benefit from:}

- Convenient online submission

- Rigorous peer review

- Open access: articles freely available online

- High visibility within the field

- Retaining the copyright to your article

Submit your next manuscript at $\boldsymbol{\nabla}$ springeropen.com 